\title{
Reporting Concerns about Earnings Quality: An Examination of Corporate Managers
}

\begin{abstract}
Using an experiment with corporate financial managers (e.g., CFOs, controllers), we find that when red flags are present in the financial statements under their review, managers identify those red flags and, in turn, have greater concerns over earnings quality. In addition, when pressure to meet a financial target is high, managers are more concerned about earnings quality when red flags are present. We also document that when red flags are present, managers are more likely to report both internally to their $\mathrm{CEO}$ and, if their concerns are not resolved internally, externally to their auditor. Pressure to meet a financial target directly influenced the decision to report internally, but not externally. Additional analyses contemplate the countervailing personal costs associated with reporting or not reporting earnings quality concerns. We demonstrate the important role short-term costs play in external reporting decisions. Finally, we provide initial evidence that corporate managers with a longer tenure at their position (public accounting background) are less (more) likely to report externally.
\end{abstract}

Keywords: earnings management, earnings quality, fraud, red flags, reporting, whistleblowing 


\section{Introduction}

Earnings management is a "phenomenon that ranges from legitimate managerial activities at one end of the spectrum to fraudulent financial reporting at the other" (POB 2000). Dichev et al. (2013) demonstrate that Chief Financial Officers (CFOs) acknowledge that earnings management occurs and that CFOs are able to list red flags that signal earnings management. Many of the red flags listed by the CFOs (e.g., high accruals) are associated with incidences of extreme earnings management or fraudulent financial reporting (hereafter, "fraud") (Dechow et al. 2011; Gullkvist and Jokipii 2013). ${ }^{1}$ Given 1) CFOs are financial gatekeepers who possess knowledge of fraud red flags, and 2) it is possible for frauds to arise without the CFO's initial involvement (e.g., at a division/regional level, directed by the $\mathrm{CEO} /$ prior $\mathrm{CFO}$, etc.), it is important to understand if, and to what extent, these managers react to red flags in the financial statements their companies prepare for external parties.

While we are not aware of a definitive rate at which frauds do not initially emanate from the CFO, the Association of Certified Fraud Examiners (2016) report that $65 \%$ of its cases of financial statement fraud were perpetrated outside the realm of executives/upper management (e.g., perpetrated in the Sales department). Beasley et al. (2010) find that, based on SEC enforcement releases, $35 \%$ of cases do not name the CFO as being associated with the fraud. Feng et al. (2011) observe that $40 \%$ of SEC enforcement releases do not name the CFO and conclude from their analyses "that CFOs are involved in material accounting manipulations because they succumb to pressure from CEOs." High profile frauds that emanated either above or below the CFO include Parmalat, Satyam, Xerox, Wells Fargo, Citigroup, Global Crossing,

\footnotetext{
${ }^{1}$ Our experimental study manipulates red flags at levels observed by prior research that has examined fraudulent companies (e.g., Brazel et al. 2009), but does not include the actual detection of fraud. Thus, we use "extreme earnings management" and "potential fraud" interchangeably.
} 
JDN Reality, Solectron, and Thor Industries. In addition, our discussion also relates to CFOs hired during the course of a multi-year fraud (e.g., HealthSouth, Livent). Indeed, CFOs note that a change in financial management is a signal that can be used to detect earnings management (see Table 14 in Dichev et al. 2013) and Feng et al (2011) observe that CFOs are apt to leave their companies prior to periods of accounting manipulation. Last, a fraud could emanate from an acquired company or prior to a merger (e.g., Cendant). ${ }^{2}$

In this study, we explore a commonly occurring context where the CFO ("manager") is reviewing consolidated financial statements prepared by a corporate controller. The task of preventing and detecting potential frauds in organizations lies with the company's management team, and management review is a primary way in which frauds are detected (e.g., IAASB 2009; AICPA 2015;ACFE 2016). Consistent with Dyck et al. (2010) who find employees often play a key role in fraud detection, a recent study reports that employees are the source of over $50 \%$ of fraud tips (ACFE 2016). Consequently, it is important not only to understand whether managers are able to recognize the red flags that indicate potential fraud, but also whether they are apt to respond to such risks by reporting concerns to the appropriate party(ies).

We investigate whether managers' concerns over earnings quality increase when red flags are present in the financial statements under their review. We also examine whether managers report their concerns about the quality of earnings when confronted with red flags. Specifically, when red flags are present, are managers inclined to report concerns internally within the company (e.g., to their CEO)? Subsequently, if their concerns are not resolved within the company, are they apt to report their concerns externally (e.g., to their external auditor)?

\footnotetext{
${ }^{2}$ For an illustration of our setting, see the following description of the fraud at Livent (https://www.theglobeandmail.com/report-on-business/former-livent-cfo-numb-over-extent-offraud/article17987583).
} 
Finally, if red flags are present in a scenario where the company faces pressure to meet a financial target, does such pressure further increase managers' concerns over earnings quality and/or impact the likelihood of reporting such concerns?

We conduct an experiment with 204 corporate financial managers (e.g., CFOs, controllers) from Italian companies. To our knowledge, we are the first study to engage corporate managers in an experiment that examines their reactions to red flags indicative of extreme earnings management and/or a potential fraud. ${ }^{3}$ Prior research has identified multiple red flags that indicate an increased likelihood of earnings management and/or fraud (e.g., Beasley 1996; Dechow et al. 2011; Dichev et al. 2013; Gullkvist and Jokipii 2013). In addition, the CFOs in Dichev et al. (2013) list avoiding the violation of debt covenants as a pressure that motivates earnings management (see also and Dechow et al. 1996; Graham et al. 2005). Informed by this literature, our experiment manipulates the presence of red flags in the financial statements (present or not present) and the pressure to meet a debt covenant (higher or lower).

Participants were asked to assume the role of $\mathrm{CFO}$ of a manufacturing company and to conduct a preliminary review of the company's consolidated financial statements. They were also informed that the corporate controller (working directly under them) was primarily responsible for preparing the financial statements. Following the case information, participants were asked questions about the financial statements they reviewed and the actions they would take based on their review. Finally, participants responded to demographic questions.

\footnotetext{
${ }^{3}$ Reporting concerns over unethical/illegal acts, including financial statement fraud, is a global concern that has led standard setters across the world to take action to improve reporting (e.g., Dodd-Frank Act in the U.S. and the Responding to Non-Compliance with Laws and Regulations Pronouncement issued by IESBA) (Verschoor 2012; IFAC 2016). The examination of Italian CFOs represents a rich context to study corporate manager concerns over financial reporting quality. Callao and Jarne (2010) report that earnings management has intensified since the adoption of IFRS in Europe as discretionary accruals have increased in the periods following adoptions. For a discussion of earnings management in European private firms see Van Tendeloo and Vanstraelen (2008) and see Leoni and Florio (2015) for a comparative history of the US and Italian earnings management literatures.
} 
We find that when red flags are present, managers identify those red flags and, in turn, have greater concerns over earnings quality. When pressure to meet a debt covenant is higher (versus lower), we observe that participants are more concerned about earnings quality when reviewing financial statements exhibiting red flags. This finding is consistent with the idea that pressure to meet financial targets is a root cause of fraud (e.g., the fraud triangle (Cressey 1953)) and managed earnings (Dichev et al. 2013). We also document that when red flags are present, managers are more likely to report both internally to their CEO and, if their concerns are not resolved internally, externally to their auditor. Although pressure to meet a financial target directly impacts reporting internally, it does not moderate the positive relations we observe between the presence of red flags and the likelihood of reporting internally and externally.

In supplemental analyses, we consider the countervailing short-term and long-term personal costs of reporting and not reporting earnings quality concerns. We find that when pressure is high and red flags are present, managers perceive a substantial short-term cost to their career if they are somehow deemed responsible for an adjustment to earnings. As such, they are less likely to report their earnings quality concerns to their external auditor. We do not find that the long-term costs of not reporting (long-term career and litigation concerns) impact the decision to report externally. Last, we provide initial evidence that corporate managers with a longer tenure at their position (public accounting background) are less (more) likely to report externally.

Our study makes important contributions to the literature. Dichev et al. (2013) note that "there is considerable potential for further research into the detection of opportunistic earnings management." Given that corporate financial managers are arguably the guardians of earnings quality, it is important to consider whether they 1) recognize red flags that signal a potential 
issue with the financial statements, and 2) are willing to report their concerns about earnings quality. Dichev et al. (2013) have shown that CFOs are able to list the signs of earnings management. We extend this line of literature by testing whether these managers are also able to recognize when these red flags are present in financial statements under their review. Furthermore, since merely recognizing financial reporting issues is often viewed as an inadequate response (Scannel and Latour 2004), we provide initial insights into factors that impact the likelihood of reporting concerns both internally to the CEO and externally to the auditor. Importantly, we document the role short-term personal costs play in inhibiting external reporting decisions. Finally, to our knowledge, we are the first to investigate whether and how the pressure to meet a financial target impacts the willingness of management to report concerns over earnings quality. Such examinations are important given the significant costs of fraud to investors, creditors, firms, etc. (e.g., NASAA 2006; Karpoff et al. 2008; Beasley et al. 2010). Our results should be of interest to corporate managers, those charged with governance, regulators, auditors, standard setters, and debt and equity market participants as they attempt to find ways to prevent and detect extreme earnings management/fraud. Given the crucial role employees play in reporting financial statement fraud (e.g., ACFE 2016; ACFE 2014; Dyck et al. 2010), understanding the propensity of managers to act is particularly important. Our findings contribute to the whistleblowing literature by highlighting the ability of corporate managers to identify and report earnings quality concerns when red flags are present in financial statements. Our results are promising in that managers recognize red flags. However, even when red flags are present and pressure is higher, we observe only a moderate likelihood that managers will report concerns to an external party. Even in extreme conditions, managers are hesitant to blow the whistle externally. 
This paper is organized as follows: Section 2 provides the theory and hypotheses.

Sections 3 and 4 describe the research method and results, respectively. The final section provides conclusions.

\section{Theory and Hypotheses}

\subsection{Recognizing the signs of earnings management}

The task of preventing and detecting misstatements in the financial statements lies with company management (e.g., IAASB 2009; AICPA 2015; PCAOB 2015). Although CFO-level managers do not prepare financial statements, they are the financial gatekeepers and oversee the financial reporting process. These managers typically review the financial reporting package for reasonableness and accuracy (Feng et al. 2011; IFAC 2013). Given the breadth of knowledge necessary to fulfill their responsibilities, these managers commonly have a background in finance or accounting and/or a strong working knowledge of financing/operations (Dichev et al. 2103). Since frauds often arise without the CFO's initial involvement (e.g., Parmalat, Satyam, Xerox), it is important to understand if, and to what extent, these managers react to the presence of red flags in their company's financial statements. In order to detect earnings management or fraud in financial statements, managers must first be able to recognize the signs (Gullkvist and Jokipii 2013).

In a survey of U.S. CFOs, Dichev et al. (2013) asked the managers to list red flags that may be present when a company is misrepresenting their reported performance. Many of the red flags identified by the CFOs in the survey (e.g., high accruals) are also associated with incidences of fraudulent financial reporting (Dechow et al. 2011). ${ }^{4}$ However, the survey did not test whether the managers are able to actually identify red flags during the course of their review

\footnotetext{
${ }^{4}$ Dichev et al. (2013) specifically excluded the examination of fraudulent financial reporting.
} 
of the financial reporting package. Recent research has found that other players in the financial reporting process (i.e., auditors, retail investors) are not apt to detect such red flags (Brazel et al. 2014; Brazel et al. 2016b). Still, given the expertise required to assume a financial management role and CFOs' knowledge vis-à-vis red flags (Dichev et al. 2013), it is reasonable to expect that managers would be sensitive to red flags indicative of extreme earnings management. As such, we predict that managers will have greater concerns over earnings quality when red flags are present. $^{5}$

When the pressure to meet a financial target (e.g., debt covenant ratio, earnings forecast) is higher, the aforementioned positive relation between the presence of red flags and earnings quality concerns may be more acute for at least two reasons. First, according to attentional theories, pressure can increase attention and effort exerted while performing tasks (e.g., Baumeister 1984; Ashton 1990). Consistent with this, if a company is close to a financial target and pressure is higher, then managers may be more thorough in reviewing the financial reporting package.

Second, managers may be more inclined to believe earnings management has occurred if a target has just been met because it is common practice to manage earnings to reach such targets (Dechow et al. 1996; Graham et al. 2005; Dichev et al. 2013;). A mature stream of literature in accounting documents the importance and regular occurrence of firms "meeting or just beating" financial targets (e.g., Burgstahler and Eames 2006). Meeting financial targets is of great concern

\footnotetext{
${ }^{5}$ According to context theory, more than one cue may be needed to allow an information recipient to interpret a story, as individuals base their interpretations of a cue on the context in which the cue is presented. A single cue may have multiple interpretations depending on the context (Estes 1986; Medin et al. 1993; Medin and Schaffer 1978). In the context of fraud red flags, a single red flag may have a reasonable explanation, leaving room for ambiguity (Brazel et al. 2016b). However, when multiple red flags are present, which is typically the case with accounting fraud (e.g., Dechow et al. 2011; Hogan et al. 2008), this ambiguity is reduced. Consequently, in our study, we examine a situation where multiple red flags are present (versus not present) to reduce the level of ambiguity in relation to whether or not the financial statements are indicative of extreme earnings management or a potential fraud.
} 
to managers, as evidenced by the negative market reaction to misses, managers' preferences to sacrifice long-term value to reach targets, and fear of creditor interference due to debt covenant violations (e.g., Burgstahler et al. 2006; Graham et al. 2005). Thus, consistent with pressure to meet financial targets being a root cause of both fraud (e.g., the fraud triangle (Cressey 1953)) and managed earnings (Dichev et al. 2013), we expect that when pressure is higher, managers will be more concerned about earnings quality when reviewing financial statements exhibiting red flags. Hypotheses $1 \mathrm{a}$ and $1 \mathrm{~b}$, stated formally, are as follows:

H1a: Managers have greater concerns over earnings quality when red flags are present (versus not present).

H1b: The positive effect of red flags on managers' concerns over earnings quality is stronger when the pressure to meet a financial target is higher (versus lower).

\subsection{Reporting concerns over earnings quality - internally and externally}

Once red flags are detected in the financial statements, the manager must then decide whether or not to act on his/her concerns. According to Schultz et al. (1993), the willingness of individuals to report concerns over earnings quality is dependent upon the perceived seriousness of the irregularity, personal responsibility for reporting, and personal costs of reporting.

Managers in a CFO-level position understand the gravity or seriousness of misrepresentations of financial statement information. Hennes et al. (2008) demonstrate that the turnover rate for CFOs involved in a restatement over an accounting irregularity is 85 percent. Feng et al. (2011) describe how CFOs bear substantial legal costs when involved in material accounting manipulations. Thus, if red flags indicative of potential fraud are present in the financial statements they are reviewing, CFOs should perceive this to be a serious irregularity.

As discussed above, the financial statements typically fall within the purview of the corporate financial managers/CFOs, which should ensure a high level of personal responsibility 
for reporting concerns over earnings quality (Feng et al. 2011). As such, when red flags are present in financial statements, this should result in both the seriousness and personal responsibility factors being high - in other words, the likelihood that the manager reports his/her concerns should increase. However, the personal costs associated with managers' reporting concerns may be slightly more complex.

The CFO has an incentive to not report concerns internally. Given the responsibility the CFO has in leading the financial reporting process, he/she may view the indication of earnings quality issues as a failure of some sort in the system they manage (Feng et al. 2011). Nevertheless, a bigger or more costly risk to the CFO would likely be that a material misstatement in the financial statements is later discovered and comes as a surprise to their CEO. Indeed, the market's reaction to restatements is often significantly negative (e.g., Myers et al. 2013).

By sharing their concerns with the CEO, which follows established lines of communication and authority, managers are able to keep the CEO apprised of the situation and may even view doing so as a shift in responsibility. Indeed, those reporting concerns over fraud are most likely to convey their concerns to their direct supervisor (Schultz et al. 1993; ACFE 2016; IFAC 2016). ${ }^{6}$ Also, the CEO carries with him/her the same pressure to meet financial targets, but also produce reliable financial statements. As a result, when red flags are present, reporting concerns to the $\mathrm{CEO}$ may reduce the personal costs incurred by the CFO.

\footnotetext{
${ }^{6}$ One of the most prominent instances of a manager reporting earnings quality concerns internally to the CEO is the case of Enron Vice President Sharon Watkins reporting her concerns to CEO Ken Lay (http://enron-online.com/wpcontent/uploads/2011/10/watkinsmemo.pdf). Related to our examination of reporting externally in the event internal concerns are not placated (see $\mathrm{H} 3 \mathrm{a}$ and $\mathrm{H} 3 \mathrm{~b}$ ), some have criticized Watkins for not reporting her concerns externally after exhausting her internal efforts (http://www.forbes.com/2002/02/14/0214watkins.html).
} 
Consequently, we predict that the presence of red flags results in managers being more likely to raise concerns internally to the CEO.

The motivation to report concerns to the CEO may be particularly high when the pressure to meet financial targets is high and, in turn, the stakes are greater. Although market reactions to restatements are typically negative (e.g., Myers et al. 2013), a subsequent restatement that causes the company to miss a previously met financial target would likely compound this effect. If misstatements are later identified that coincide with just meeting a financial target, it is likely that the misstatements could be viewed as intentional by financial statement users and regulators (versus as a result of error) (Graham et al. 2005). The CFO is the leader of the accounting function (IFAC 2013), and company insurance policies do not cover firm management when courts find the firm guilty of fraud (Dyck et al. 2010). Thus, the personal costs to the manager of not reporting earnings quality concerns internally are even higher when there is pressure to meet a financial target. As a result, in higher-pressure settings, we expect managers who observe red flags to be even more likely to raise concerns to the CEO. Hypotheses $2 a$ and $2 b$, stated formally, are as follows:

H2a: Managers are more likely to report concerns over earnings quality internally when red flags are present (versus not present).

H2b: The positive effect of red flags on managers reporting earnings quality concerns internally is stronger when the pressure to meet a financial target is higher (versus lower).

If a manager raises concerns over earnings quality inside the company and those concerns are not adequately resolved, the manager must then decide whether or not to report the concerns externally. ${ }^{7}$ Managers are likely to consisder external control mechanisms when internal parties

\footnotetext{
${ }^{7}$ Extant research suggests that managers are more apt to report concerns internally over externally (e.g., Robertson et al. 2011; Brink et al. 2013). Consistent with this notion, demographic data from our participants (presented in Table 1 and discussed in Section 3) illustrate a strong preference for reporting internally versus externally. Given this preference, we designed our experiment such that participants chose to report internally first and then
} 
fail to respond to their earnings quality concerns (Dyck et al. 2010). The dynamics of the personal costs to the manager change, however, when reporting to external parties (e.g., external auditor) versus internally to the CEO.

When reporting concerns internally to the CEO, the financial reporting incentives of the manager are typically aligned with the CEO. As a result, reporting concerns to the CEO is more likely to be an open dialogue about whether or not adjustments need to be made to correct for any misrepresentation. Conversely, if the manager's concerns regarding earnings quality are valid, external parties are more independent of the company's financial performance and tend to care much less about the company meeting financial targets. If the financial statements are misstated, reporting to an external party like the auditor is more likely to lead to adjustments that correct the earnings management (Nelson et al. 2003). In other words, an adjustment to the financial statements is likely (i.e., usually a downward adjustment to earnings (Kinney and Martin 1994)). Thus, if a manager reports earnings quality concerns to an external party, there are additional personal costs to consider. For example, the social costs and retaliation faced by employees that blow the whistle externally are significant and well documented (e.g., Carson et al. 2008; Jos et al. 1989). Dyck et al. (2010) anecdotally describe the personal effects for managers who blow the whistle on fraud with consequences including termination, poor job prospects, imprisonment, litigation, and threats/intimidation.

Still, not reporting concerns externally when red flags are present could also yield negative outcomes or personal costs to managers. If red flags are present in financial statements and managers do not raise concerns, earnings quality issues may be subsequently discovered. In such settings, managers could suffer substantial repercussions both professionally and

considered reporting externally only after "inside the company nothing was done in response to your concern." We believe this design choice reflects the decision-making process managers would employ in practice. 
personally. For example, the managers who expressed accounting concerns internally in high profile frauds like Enron faced federal indictments because they did not subsequently report externally when their concerns were not placated (Scannel and Latour 2004). In analyzing 216 major cases of alleged fraud, Dyck et al. (2010) note that avoiding legal liabilities arising from being associated with a fraud was a substantial factor in employees deciding to express concerns externally. In addition, anecdotal evidence from high-profile fraud cases suggests that it is not uncommon for the CEO to direct financial statement frauds (e.g., Satyam, Parmalat (Soltani 2014; Melis 2005)), and these frauds are likely to be perpetrated by accounting department staff (e.g., ACFE 2014; Feng et al. 2011). Indeed, Feng et al. (2011) find that CEOs with higher compensation incentives and power drive accounting manipulations and CEOs are often described in SEC enforcement releases as the orchestrator of such manipulations. As such, it is possible for the $\mathrm{CFO}$ (or other corporate financial managers) to be caught between the director(s) and perpetrator(s) of a financial statement fraud. An inadequate internal response may indicate CEO involvement and should increase the sense of personal responsibility in the manager. Consequently, when red flags are present, we expect that managers will report concerns over earnings quality externally if the CEO is made aware of the situation and does not act. ${ }^{8}$

Hypothesis 3a, stated formally, is as follows:

H3a: If concerns over earnings quality are not adequately resolved inside the company, managers are more likely to report their concerns externally when red flags are present (versus not present).

The degree of pressure faced by managers or the margin of error in meeting a financial target may also impact the likelihood that managers report their concerns over earnings quality

\footnotetext{
${ }^{8}$ See http://ww2.cfo.com/fraud/2014/03/whistleblowers-trilemma for further discussion of the dilemma CFOs face when deciding to report earnings quality concerns externally and http://www.cfo.com/printable/article.cfm/3690780 for an example of a CFO reporting accounting concerns externally.
} 
externally. In terms of reporting earnings quality concerns internally, as mentioned above, the manager and CEO's financial reporting incentives are aligned (i.e., both are motivated to meet financial targets). This, combined with evidence that executives are often willing to "get creative" and use the discretionary piece of earnings to meet financial reporting targets (e.g., Dichev et al. 2013), suggests that sharing concerns with the CEO in high pressure situations may allow the manager to not only resolve the earnings quality issue, but to do so without missing any targets. Indeed, "the market believes that most firms can "find the money" to hit earnings targets" (Graham et al. 2005).

When reporting externally (e.g., to the external auditor), however, the manager is increasing the likelihood that any earnings management is not only detected but also adjusted (Nelson et al. 2003). Accordingly, there may be more significant personal costs involved in reporting externally, especially if the company is facing a high level of financial reporting pressure. In a high-pressure setting, adjustments to the financial statements that stem from reporting externally may cause the company to not meet a financial target. For example, an adjustment to the financial statements could lead to a violation of a debt covenant that causes the bank to call a loan and the external auditor to issue a going concern opinion (DeFond and Jiambalvo 1994). A negative earnings surprise can lead to costly turmoil in equity markets as well (Graham et al. 2005). As such, multiple stakeholders would be affected, likely resulting in a severe backlash against the manager. Dyck et al. (2010) report that in 82 percent of cases where an employee blew the whistle on a fraud, the employee claims they were fired, subsequently quit due to duress, or had their job responsibilities significantly altered.

Thus, in higher-pressure situations, managers face countervailing personal costs. If a manager reports their concerns externally, they are likely to cause a negative adjustment to 
earnings, negatively affecting their career in the short-term. On the other hand, if they do not report externally and an issue becomes known later, they may face long-term personal costs and legal liabilities. Again, misstatements identified later that coincide with just meeting a financial target are likely to be viewed as intentional by financial statement users and regulators. Consequently, given the countervailing personal costs of reporting externally when pressure is higher, it is unclear whether pressure to meet a financial target will affect the positive relation between the presence of the red flags and the decision to report concerns externally. ${ }^{9}$ Thus, we state Hypothesis $3 \mathrm{~b}$ in the null form:

H3b: The positive effect of red flags on managers reporting earnings quality concerns externally is not affected by the pressure to meet a financial target.

\section{Method}

\subsection{Participants}

Two hundred and four corporate managers completed an online experimental instrument for this study. To obtain our sample of participants, we first contacted 1,052 privately held and publicly traded Italian companies obtained from Aida - Bureau Van Dijk (https://aida.bvdinfo.com, a database of public and private Italian companies), as well as from corporate contacts developed by one of this study's investigators. We contacted a management representative for each company directly, and 951 companies agreed to participate in the study. For companies that agreed to participate, we obtained names and email addresses for corporate managers in the accounting and corporate finance areas. We targeted chief financial officers (CFOs) first and, if no response was obtained, we contacted controllers and other related

\footnotetext{
${ }^{9}$ In our experimental study, we measured such countervailing personal costs and perform additional analyses related to these costs in Section 4.
} 
corporate managers. ${ }^{10}$ Managers were contacted via email and provided with a link to the online research instrument (described below), which was administered via Qualtrics (there were three follow-up emails to encourage participation). Two hundred and twenty managers began the instrument, 14 of those managers did not complete the instrument, and we removed two observations completed by the same participant, leaving a sample of 204 managers. ${ }^{11}$ Our response rate of $19.4 \%(204 / 1,052)$ is greater than the response rates of prior studies that have engaged corporate managers in the areas of accounting and corporate finance (e.g., Dichev et al. 2013; Evans et al. 2015; Graham et al. 2005; Brazel et al. 2016a). ${ }^{12}$

Table 1 provides demographic data for our participants and their companies. We have an experienced set of participants, with $38.73 \%$ and $27.45 \%$ being CFOs and controllers, respectively. Participants have, on average, 10-19 years of experience at their job, are between 40-49 years of age, and hold an undergraduate degree. ${ }^{13}$ Given their management positions, and consistent with our discussion above, $100 \%$ of our participants are involved with the production of financial statements and $83.82 \%$ are in some manner responsible for their companies' financial statements. Our participants are also apt to search for red flags when they review the financial statements of their company (see variable 5 with an average response of 5.28 out of 7).

\footnotetext{
${ }^{10}$ After the Parmalat scandal, the Italian Government edited Law no. 262 (Italian Law No. 262 2005), which now requires disclosures of the CFO for all Italian companies (prior to the law change this information was only disclosed for publicly listed companies). This change aimed to increase the transparency of corporate financial disclosure and create a more effective system of internal controls. The CFO became jointly responsible (with the CEO) for financial reporting.

${ }^{11}$ Qualtrics allows researchers to conduct several follow-up procedures targeting all participants. Due to the nature of the follow-up procedures, it is possible for a participant to start the research instrument and not complete it. Then, when a link to the instrument is provided in a follow-up email, that same participant could start the instrument again (versus restarting the incomplete instrument) and complete it.

${ }^{12}$ Similar to Dichev et al. (2013), to guard against someone other than the manager completing the instrument (e.g., an administrative assistant), we asked for extensive personal information and specific data about the manager's company in the post-experimental questionnaire (see Table 1).

${ }^{13}$ According to a 2010 EY survey of 669 CFOs from Europe, the Middle East, India, and Africa, only $27 \%$ had obtained the MBA degree

(http://www.ey.com/Publication/vwLUAssets/Estudio_DNA_CFOs_2010/\$FILE/DNA_CFOs_2.pdf).
} 
Participants reported being highly likely to report red flags internally to a superior, with an average response of 6.33 out of 7 and a relatively low standard deviation of 1.04. This is indicative of substantial consensus amongst managers to report earnings quality concerns internally. On the other hand, these managers are less likely to report concerns to a whistleblower hotline or someone external to the company, with average responses (standard deviations) of 3.91 (2.36) and 4.22 (2.27), respectively. These responses are consistent with Taylor and Curtis (2010) and Brink et al. (2013), who find that employees are more likely to report concerns over earnings quality internally, rather than externally. Note also that the standard deviations for reporting via a hotline or externally are more than twice the magnitude of reporting internally, indicating less consensus amongst managers regarding these two reporting options. This lack of consensus may reflect the countervailing personal costs of reporting externally, as noted previously. We measure, in the context of our experiment, the likelihood our participants would use multiple internal and external reporting outlets (see footnotes 22 and 23). Participants' companies have, on average, between $\$ 100-\$ 499$ million in total sales and between $25 \%-50 \%$ of total sales are foreign sales. Consistent with the Italian economy being dominated by privately held companies, $81.86 \%$ of our participants work for privately held companies. ${ }^{14}$ The mean company age is 41.83 years, and the most common industries are

\footnotetext{
${ }^{14}$ Burgstahler et al. (2006) document that, within the European Union, private companies are much more prevalent than public companies and private companies exhibit higher levels of earnings management. In Italy, approximately 360 companies are publicly listed (http://www.borsaitaliana.it/homepage/homepage.htm) and 7,500 companies are owned by the State (http://www.panorama.it/economia/aziende/aizende-pubbliche-quanto-costano-stato/), while 5.3 million companies are privately owned (http://www.digital4.biz/pmi/approfondimenti/quasi-53-milioni-le-impresein-italia_4367215623.htm). We acknowledge that private company managers do not face the pressures associated with widely dispersed investors, which may affect their willingness to report red flags (e.g., the market reaction to restatements is not as forefront in their minds as it would be for managers of publicly traded companies). On the other hand, the required public disclosure of both public and private company CFOs in Italy (see footnote 10) likely has elevated accountability levels amongst CFOs similar to the certification of quarterly and annual reports in the U.S. under the Sarbanes-Oxley Act of 2002. To investigate differences between private and public company participants, we compare the responses provided by private and public company managers in our most extreme condition (PRESSURE high and RED FLAGS present or Condition 4 as described in Figure 1 and Table 2). Mean
} 
manufacturing, service/consulting, and retail/wholesale. Finally, $65.33 \%$ of the participants'

companies were audited by an international accounting firm (versus an Italian accounting firm).

Given that our study extends the work of Dichev et al. (2013), we compare our

demographic data in Table 1 to that obtained from the survey participants in Dichev et al. (2013)

who worked for private U.S. companies (see Table 1 in Dichev et al. (2013), where 54.93\% of

participants worked for a private company). Like our sample, the private company CFOs in

Dichev et al. (2013) are most likely managing a manufacturing company with between $\$ 100$ -

$\$ 499$ million in sales. As one would expect, given that Italy is a smaller marker than the U.S., our participants report a higher proportion of foreign sales. Our participants are also slightly

younger, but have greater experience in their position. Last, the percentage of our participants

with a public accounting background (41.32\%) is very similar to the $41.26 \%$ observed by Dichev

et al. (2013). ${ }^{15}$

\subsection{Description of the experimental context}

The experimental materials placed participants in the position of CFO of a hypothetical

company named Tecno Sporting Goods, a manufacturer of sporting goods equipment consisting

of four divisions. ${ }^{16}$ Their task was to perform a preliminary, top-level review of Tecno Sporting

responses for CONCERN, INTERNALLY, and EXTERNALLY are not significantly different (p's > .05) between private and public company managers.

${ }^{15}$ With respect to total company sales and age, our participants are also similar to the corporate managers in Evans et al. (2015).

${ }^{16}$ Instruments were provided online and in Italian, the native language of the participants. The instruments were first developed in English. To develop the Italian versions of the instruments, we followed the translation-back

procedures outlined by Brislin (1986). Specifically, in the first stage, the experimental instruments were translated from English to Italian by one of the authors who is fluent in both languages. Then, another independent academic translated the Italian version back to English (back-translated English version). The original and back-translated English versions were then compared, and all discrepancies resolved by the translators. In a second stage, to assure that the materials would be realistic and understood by respondents, the instrument was carefully pre-tested. First, the instruments were discussed with Italian academic scholars to assess the clarity of the instruments. Afterwards, a pilot study was also conducted with a group of accounting managers from three Italian companies (with their input being incorporated into the instruments). Finally, the final instruments were reviewed once more by a panel of three Italian academic scholars. 
Goods' consolidated, year-end financial condition. Participants learned that Tecno's main financing came in the form of loans from First National Bank, and that the bank required audited financial statements annually. Tecno's debt covenant with First National Bank required that they meet several financial ratios. Participants were informed that if there was a debt covenant violation, the bank had the right to require that all future payments under the loans be due immediately. The materials also provided participants with additional information about Tecno and its industry, including product and customer information, industry sales, and highlights from a recent business news article.

Participants were also told the following:

Tecno Sporting Goods consists of four divisions that are consolidated for financial reporting purposes. Each division has a controller in charge of preparing the division's financial statements. The corporate controller (who works directly under you) is in charge of consolidating the divisions' financial statements into one set of financial statements for Tecno Sporting Goods. Your corporate controller is primarily responsible for preparing Tecno Sporting Goods' consolidated financial statements.

Participants were informed that, in order to perform their top-level review of Tecno's financial condition, they asked their corporate controller for: 1) preliminary 2013 Tecno consolidated financial statements (along with comparative financial statements from the two prior years), 2) financial ratio calculations, and 3) important non-financial data for Tecno (e.g., employee headcounts, number of patents).

\subsection{Independent variables}

The experiment manipulated two variables between subjects, each at two levels, resulting in four experimental conditions. Figure 1 illustrates the four experimental conditions. The first manipulated variable was the presence of red flags, manipulated as red flags either being present or not present in the current year financial statements under review (this variable is referred to as "RED FLAGS" below). 
Dichev et al. (2013) describe the challenge of isolating red flags that effectively signal earnings management. However, their surveys and interviews of CFOs suggest that companies managing earnings typically exhibit multiple red flags (e.g., Table 14 of Dichev et al. (2013) lists 20 red flags, each identified by multiple CFOs). Many of these red flags (e.g., high accruals) are also associated with incidences of fraudulent financial reporting (e.g., Dechow et al. 2011; Gullkvist and Jokipii 2013). Consistent with the findings reported in Dichev et al. (2013), research has concluded that in the case of extreme earnings management or fraud, firms typically exhibit multiple red flags prior to detection (e.g., Hogan et al. 2008; see also footnote 5). Because we are interested in determining how the presence of red flags induces manager concerns over earnings quality and reporting behavior, we manipulate multiple (two) red flags at levels of both fraud and non-fraud companies (for our RED FLAGS present and not present conditions, respectively).

The CFOs in Dichev et al. (2013) most frequently cited earnings that are inconsistent with cash flows (i.e., high accruals) as a red flag for earnings management. DeFond and Jiambalvo (1994) observe that companies manage earnings through accruals to meet debt covenants. Likewise, both Lee et al. (1999) and Dechow et al. (2011) illustrate that fraud firms have significantly higher levels of accruals as compared to non-fraud firms. Thus, for our RED FLAGS present condition, the first red flag we manipulate is the accrual red flag. The accrual red flag is manipulated as present or not present, based upon the findings of Lee et al. (1999) and Brazel et al. (2009). For the RED FLAGS present (not present) condition, accruals represented $11 \%(1 \%)$ of total assets. ${ }^{17} \mathrm{We}$ manipulated the level of positive accruals, as net income

\footnotetext{
${ }^{17}$ Because the measurements of the accrual red flag for fraud (15\% of total assets) and non-fraud firms (1\%) provided by Lee et al. (1999) may be dated, we averaged their findings with the accrual red flag measure of Brazel et al. (2009). Brazel et al. (2009) observe the accrual red flag for fraud (non-fraud) firms to be $7 \%$ (0\%) of total assets.
} 
exceeded cash flow from operations in both conditions. Financial statement data on the income statement and balance sheet were kept constant in all conditions, while current year cash flow from operations was altered to achieve high and low accrual levels.

Companies managing earnings are often referred to as companies that misrepresent their economic performance or the results of operations (e.g., Dichev et al. 2013). Companies disclose non-financial measures ("NFMs," such as number of patents, production space, and employee headcount) that reflect key aspects of performance/operations and represent measures of economic activity (Francis et al. 2003; Schultz et al. 2010). Both Brazel et al. (2009) and Dechow et al. (2011) document that fraud firms exhibit substantial differences between growth in their reported financial measures (e.g., revenue growth) and growth in related NFMs (e.g., growth in employees and stores). Thus, the second red flag we manipulate is the NFM red flag. In all conditions, the current year's sales growth was $6 \%$. In the RED FLAGS present condition, participants observed current year NFM growth of, on average, -19\% (25 percentage points different from sales growth). For the RED FLAGS not present condition, participants observed current year NFM growth of, on average, $0 \%$ (6 percentage points different from sales growth). While the rate of NFM growth was manipulated between participants, the types of NFMs provided to participants were kept constant (e.g., number of employees, product lines, patents). ${ }^{18}$ In sum, in the RED FLAGS present condition, both the accrual and NFM red flags were present. In the RED FLAGS not present condition, neither the accrual nor the NFM red flag were present. For all participants, prior year accruals were low and prior year sales and NFM growth were consistent (i.e., both accrual and NFM red flags were not present in the prior year). As

\footnotetext{
${ }^{18}$ We relied on the descriptive data of Brazel et al. (2009) to manipulate the sales/NFM relation in a realistic manner. The NFM red flag observed by Brazel et al. (2009) compares sales growth to the average growth of related NFMs (all NFMs are equally weighted). Our manipulation reflects this treatment.
} 
described above, given the breadth of knowledge necessary to complete the tasks of a CFO effectively, these managers commonly have expertise in finance, accounting, and/or a strong working knowledge of operations. The two red flags selected for this study (accrual and NFM) are reflective of this knowledge-base. Consistent with our predictions and extending Dichev et al. (2013), manipulation checks indicate that when red flags are present, managers can identify red flags when reviewing the financial reporting package. ${ }^{19}$

The second manipulated variable was the pressure to meet a financial target (this variable is referred to as "PRESSURE" below). Related to PRESSURE, Dichev et al. (2013) asked CFOs if companies report earnings to misrepresent economic performance to avoid violation of debt covenants. Eighty-nine percent (73\%) of private (public) CFOs agreed that they did.

In the lower PRESSURE conditions of our study, participants were told the following:

You have been informed by your corporate controller that Tecno's 2013 ratio for percent return on assets from the preliminary 2013 consolidated financial statements easily exceeds the required ratio as stated in the First National Bank debt covenant.

In the higher PRESSURE conditions, participants were told the following:

You have been informed by your corporate controller that Tecno's 2013 ratio for percent return on assets from the preliminary 2013 consolidated financial statements just barely meets the required ratio as stated in the First National Bank debt covenant.

Given the expectation that most of our participants would be CFOs or controllers of privately held companies, we selected a financial target that would be relevant to both private and public companies (versus equity-based pressures). Indeed, both Bonacchi et al. (2017) and Bianchi

\footnotetext{
${ }^{19}$ Participants were post-experimentally asked to recall 1) the difference between the company's net income and cash flow from operations, and 2) the difference between the company's sales growth and growth in NFMs (measured via scales, where $1=$ "Very small" and $7=$ "Very large"). Non-tabulated results indicate that those in RED FLAGS present condition rated both of these differences to be significantly larger than those in the RED FLAGS not present condition (both p's $<0.01$ ).
} 
(2017) note that, in Italy, relationships with banks are crucial and companies manage earnings to obtain/maintain debt financing. ${ }^{20}$

\subsection{Dependent variables}

Our first dependent variable of interest is the level of the manager's concern over earnings quality (this variable is referred to as "CONCERN" below). After reviewing the experimental materials, participants responded to the following prompt:

Based on your preliminary review, net income for Tecno in 2013 is:

Participants responded on a 7-point response scale ranging from 1 to 7 , with the left endpoint labeled "Materially understated" and the right endpoint labeled "Materially overstated." The middle of the scale, which was 4, was labeled "Very accurate." We measure CONCERN as the absolute value of the participant's response from the midpoint of 4 (that earnings are very accurate). For example, if a participant responded 4, their CONCERN was 0. If a participant responded 3 or 5 , their CONCERN was 1 , and so on. Thus, our variable CONCERN ranges from 0 to 3, with higher values indicating greater concerns over earnings being either materially over or understated. ${ }^{21}$

\footnotetext{
${ }^{20}$ Related to our PRESSURE manipulation, participants were asked to recall if Tecno's percent return on assets barely met or was well above the ratio required by First National Bank (measured via scale, where 1 = "Just met" and $7=$ "Well above"). Non-tabulated results indicate that the mean response for those in the higher PRESSURE condition was significantly lower than those in the lower PRESSURE condition $(\mathrm{p}<.01)$.

${ }^{21}$ Our manipulations of PRESSURE and RED FLAGS would be more likely associated with net income being overstated than understated (e.g., pressure related to the return on assets, net income substantially higher than cash flow from operations). Indeed, only three participants in the PRESSURE high/RED FLAGS present condition (Condition 4 in Table 2) indicated concerns that earnings were understated (our tests of hypotheses are robust to excluding these three participants from our analyses). However, to avoid demand effects, we provided our participants with the option to respond that net income was understated, very accurate, or overstated. We find qualitatively similar results for our test of $\mathrm{H} 1 \mathrm{a}$ and $\mathrm{H} 1 \mathrm{~b}$ if we replace CONCERN with the 7-point response scale ranging from 1 to 7 (not the absolute value), with the left endpoint labeled "Materially understated" and the right endpoint labeled "Materially overstated." We observe qualitatively similar results for our test of H1a using scales measuring participants' perceptions of the accuracy of the financial statements, the level at which Tecno's earnings were managed, or the likelihood Tecno's financial statements were fraudulent. The latter two scales were completed by participants at the end of the study to avoid demand effects.
} 
Our other dependent variables of interest are the likelihood that the manager will report concerns over earnings quality internally (referred to as "INTERNALLY" below) and the likelihood that the manager will report concerns over earnings quality externally (referred to as "EXTERNALLY" below). We measured INTERNALLY with the following question:

You stated that the 2013 net income for Tecno may be overstated/understated. To what extent would you discuss this concern with your Chief Executive Officer (CEO)?

Whether the question indicated "overstated" or "understated" was determined by the participant's response to the aforementioned CONCERN prompt. Participants responded on a 7point response scale ranging from 1 to 7 , with the left endpoint labeled "Would not discuss" and the right endpoint labeled "Definitely discuss." We measured INTERNALLY by examining reporting intentions to the $\mathrm{CEO}$ because 1) the $\mathrm{CEO}$ is the superior to the $\mathrm{CFO}$ role the participants assumed in the study, and 2) those reporting concerns over fraud are most likely to convey their concerns to their direct supervisor (ACFE 2016). ${ }^{22}$

We measured EXTERNALLY with the following question:

You stated that the 2013 net income for Tecno may be overstated/understated. If inside your company nothing was done in response to your concern, to what extent would you discuss this concern with your external auditor?

Participants responded on a 7-point response scale ranging from 1 to 7 , with the left endpoint labeled "Would not discuss" and the right endpoint labeled "Definitely discuss." We measured EXTERNALLY by examining reporting intentions to the auditor because, for the CFO, the auditor is likely the closest independent external party to the financial statements. In addition,

\footnotetext{
${ }^{22}$ We obtain qualitatively similar results to the ones reported herein if we measure INTERNALLY with discussing their concern with the corporate controller. Discussing concerns with the corporate controller, who the instrument explicitly states is responsible for preparing the company's consolidated financial statements, would likely be a more direct method of correcting any financial reporting issues. This of course assumes that the controller is aware of any issues and/or is willing to admit to any wrongdoing, which may not be the case. We find that, when red flags are present, the mean participant response for discussing their concern with their controller $($ mean $=4.82)$ is approximately the same as the mean response for discussing their concern with their CEO (mean $=4.87)$. Thus, participants did not express a preference for one form of internal reporting over the other.
} 
both the CEO and the auditor are "part of a chain of actors" responsible for the reliability of the financial statements (IFAC 2013). ${ }^{23}$ If a participant responded to CONCERN with a "4," they were not asked questions about INTERNALLY and EXTERNALLY because such questions would be nonsensical given that they indicated that net income was "Very accurate" (i.e., there are no concerns to discuss). Participants responding "4" to CONCERN were, therefore, coded as "1" ("Would not discuss") for the INTERNALLY and EXTERNALLY variables described above. $^{24}$

\section{Results}

\subsection{Descriptive statistics}

Participants' mean responses (standard deviations) for CONCERN, INTERNALLY, and EXTERNALLY by experimental condition are presented in Table 2 and graphed in Figures 2, 3, and 4. Consistent with H1a, managers in the RED FLAGS present conditions have higher CONCERN levels (versus the RED FLAGS not present conditions). Consistent with H1b, the aforementioned effect of RED FLAGS on CONCERN appears to be stronger when PRESSURE is higher versus lower. Related to H2a, H2b, H3a and H3b, the levels of INTERNALLY and EXTERNALLY are higher when RED FLAGS are present, but it appears that the effects of RED FLAGS are not moderated by the level of PRESSURE. One last item to note is that, regardless of PRESSURE and RED FLAGS, the likelihood of reporting INTERNALLY and EXTERNALLY

\footnotetext{
${ }^{23}$ With respect to responding externally after reporting concerns internally, IFAC (2016) notes the importance of alerting the auditor under such circumstances, such that the auditor is provided with all the information that is necessary for them to complete their audit. The ACFE (2016) document that those reporting fraud externally use multiple outlets (including their auditor) to convey their concerns. We obtain qualitatively similar results to the ones reported herein if we measure EXTERNALLY with reporting to First National Bank. Alternatively, reporting concerns over earnings quality to an audit committee or an anonymous whistleblower hotline may be a less extreme step than reporting to the external auditor. We find qualitatively similar results when we asked participants to what extent they would report their concerns over earnings quality to such outlets.

${ }^{24}$ Fifty three participants ( $25 \%$ of our sample) responded to CONCERN with a "4." As one would expect, the percentage responding to CONCERN with a " 4 " was higher in the RED FLAGS not present condition (35\%) than in the RED FLAGS present condition (18\%).
} 
is typically low to moderate regardless of condition, with the exception of the extreme condition where PRESSURE is high and RED FLAGS are present. In this condition (Condition 4), participants are more inclined to report concerns over earnings quality INTERNALLY (mean = 5.46, whereas the means for all other responses range from 2.65 to 4.40 on 7-point scales). Even in our experimental setting, managers are somewhat reluctant to report earnings quality concerns, but are apt to report internally when they encounter an extreme condition.

\subsection{Testing of hypotheses}

We formally test $\mathrm{H} 1 \mathrm{a}$ and $\mathrm{H} 1 \mathrm{~b}$ using an ANOVA presented in Table 3. As predicted by H1a, there is a strong effect for RED FLAGS on CONCERN (F-statistic $=61.48, \mathrm{p}<.001)$. As depicted in Table 2 and Figure 2, and in line with our manipulation check (see footnote 19), when RED FLAGS are present, our participants identify those red flags and in turn, have greater concerns over earnings quality. Consistent with PRESSURE being a root cause of both managed earnings (Dichev et al. 2013) and fraud (e.g., the fraud triangle (Cressey 1953)), we also observe a significant effect for PRESSURE on CONCERN (F-statistic $=8.29, \mathrm{p}=.004)$. Table 2 depicts higher means under higher PRESSURE (versus lower). Related to H1b, we find a significant interaction between RED FLAGS and PRESSURE (F-statistic $=4.66, \mathrm{p}=$ .032). H1b predicts that the positive effect of red flags on managers' concerns over earnings quality is stronger when the pressure to meet a financial target is higher (versus lower). In other words, H1b predicts that the difference between Conditions 4 and 2 for CONCERN (see Table 2) should be larger than the difference between Conditions 3 and 1. Visual inspection of the means in Figure 2 suggests the form of the interaction is consistent with H1b. However, to formally test whether the form of the interaction is consistent with our hypothesis, we performed a planned contrast. Non-tabulated results confirm that the observed interaction is 
consistent with the form of the interaction posited by $\mathrm{H} 1 \mathrm{~b}$ (value of the contrast $=.54$, $\mathrm{t}$ statistic $=2.172, \mathrm{p}=.015)$.

We formally test $\mathrm{H} 2 \mathrm{a}, \mathrm{H} 2 \mathrm{~b}, \mathrm{H} 3 \mathrm{a}$, and $\mathrm{H} 3 \mathrm{~b}$ using a MANOVA presented in Table 4. Consistent with $\mathrm{H} 2 \mathrm{a}$, there is a strong effect for RED FLAGS on INTERNALLY (F-statistic $=$ 46.36, $\mathrm{p}<.001)$. The means provided in Table 2 and depicted in Figure 3 suggest that, when RED FLAGS are present, managers are more inclined to report their concerns over earnings quality INTERNALLY to their CEO. In Table 4 we also observe a significant effect for PRESSURE on INTERNALLY (F-statistic $=12.87, \mathrm{p}<.001)$. Thus, in the presence of RED FLAGS or higher PRESSURE, participants are more apt to report concerns over earnings quality INTERNALLY ${ }^{25}$ However, unlike our results for CONCERN and contrary to H2b, visual inspection of the means in Figure 3 does not depict an interaction between RED FLAGS and PRESSURE. In Table 4 we do not observe a significant interactive effect between RED FLAGS and PRESSURE (F-statistic $=1.16, \mathrm{p}=.283$ ). Thus, PRESSURE does not positively moderate the effect of RED FLAGS on INTERNALLY, but rather increases the likelihood of reporting internally regardless of whether or not red flags are present. This result may reflect our finding in Table 1 of a relatively low standard deviation for "Report internally to a superior" (variable 6 in Table 1), which is indicative of substantial consensus amongst managers to report red flag concerns internally (regardless of pressure). It also may suggest that if targets have been barely met (i.e., pressure is higher), managers will have internal discussions.

\footnotetext{
${ }^{25}$ Consistent with our development of hypotheses and our observed main effects for PRESSURE, we find significant positive relations (p's $<.05)$ between PRESSURE and the motivation/mental efforts participants reported vis-à-vis their review of the financial statements. Likewise, we find significant positive relations (p's $<.05)$ between PRESSURE and participants' perceptions that Tecno's earnings were managed/fraudulent.
} 
Supporting H3a, we observe a significant main effect for RED FLAGS on

EXTERNALLY $(\mathrm{F}$-statistic $=23.80, \mathrm{p}<.001)$. Inspection of the means for EXTERNALLY in Table 2 and Figure 4 reveal that, when RED FLAGS are present and concerns are not resolved internally, participants are more apt to report EXTERNALLY to their external auditor. Unlike the decision to report INTERNALLY, however, PRESSURE does not appear to have a direct effect on EXTERNALLY (F-statistic $=.003, \mathrm{p}=.957)$.

$\mathrm{H} 3 \mathrm{~b}$ is stated in the null form: The positive effect of red flags on managers reporting concerns externally is not affected by the pressure to meet a financial target. Consistent with this null hypothesis (and depicted in Figure 4), we do not observe a significant interaction between RED FLAGS and PRESSURE in Table 4. As indicated by the means for EXTERNALLY presented in Table 2, when RED FLAGS are present, participants were moderately willing to report EXTERNALLY, regardless of pressure. Last, Non-tabulated tests of mediation using the Hayes (2013) bootstrapping procedure also illustrate that CONCERN mediates the relations between (1) RED FLAGS and INTERNALLY (Lower CI = 1.052, Upper CI = 1.819) and (2) RED FLAGS and EXTERNALLY (Lower CI = .646, Upper CI = 1.398).

Overall, we provide strong strong evidence that managers can identify and react to the presence of RED FLAGS and mixed evidence related to the role of PRESSURE. Next, we specifically examine the countervailing short- and long-term costs associated with reporting earnings quality concerns.

\subsection{Countervailing costs of reporting concerns over earnings quality}

While bearing concerns over earnings quality may cause personal stress for the corporate manager, the act of reporting EXTERNALLY comes with significant short-term costs for the manager. When reporting externally (e.g., to the external auditor or bank), the 
manager is increasing the likelihood that any earnings management and/or fraud in the financial statements is not only detected, but also adjusted (i.e., restated). As noted previously, the short-term social costs/retaliations faced by employees that blow the whistle externally are significant and well documented (e.g., Carson et al. 2008; Jos et al. 1989). To measure this short-term cost, we asked participants in our study:

As the CFO of Tecno, please describe how your career at Tecno would be affected if you adjusted Tecno's 2013 net income downward to correct any accounting misstatements (referred to as "ADJUSTMENT"):

Participants responded on a 7-point response scale ranging from 1 to 7 , with the left endpoint labeled "Very negatively" and the right endpoint labeled "Very positively."

In non-tabulated tests of mediation using the Hayes (2013) bootstrapping procedure, we find that ADJUSTMENT significantly mediates the relation between RED FLAGS and EXTERNALLY $(\mathrm{t}=1.986, \mathrm{p}=.048, \mathrm{LLCI}=.001, \mathrm{ULCI}=.319)$. When pressure is high and red flags are present, managers perceive a substantial short-term cost to their career if they are somehow deemed responsible for an adjustment to earnings. As such, they are significantly less likely to report their earnings quality concerns to their external auditor (LLCI $=-.308$, ULCI = -.014). Thus, when PRESSURE is high and RED FLAGS are present, we observe that managers maintain the highest level of CONCERN (see Condition 4 in Table 2), but also have an incentive to not report EXTERNALLY (i.e., short-term career cost). ${ }^{26}$

However, short-term career costs associated with a potential adjustment to earnings may not be the only personal cost considered by managers when deciding to report

\footnotetext{
${ }^{26}$ Conversely, when PRESSURE is low, ADJUSTMENT significantly mediates the relation between RED FLAGS and EXTERNALLY, but in the opposite direction (LLCI $=.031$, ULCI $=.483$ ). When pressure is low and red flags are present, managers are less likely to perceive a substantial short-term cost to their career if they are somehow deemed responsible for an adjustment to earnings. As such, they are more willing to report their earnings quality concerns to their external auditor.
} 
EXTERNALLY. We also examine the long-term costs of not reporting concerns

EXTERNALLY. Feng et al. (2011) and Beasley et al. (2010) describe how CFOs of companies that manipulated earnings face future employment restrictions, legal issues, and other long-term costs. In line with these long-term costs, we asked participants in our study two questions:

As the CFO of Tecno, please describe the risk to your career if you submit the 2013 Tecno financial statements to First National Bank (assuming no adjustments are made to the financial statements) (referred to as "CAREER RISK"):

As the CFO of Tecno, please describe your risk of litigation if you submit the 2013

Tecno financial statements to First National Bank (assuming no adjustments are made to the financial statements) (referred to as "LITIGATION RISK"):

Participants responded on a 7-point response scale ranging from 1 to 7 , with the left endpoint labeled "None" and the right endpoint labeled "Very high."

Although the presence of RED FLAGS positively affects CAREER RISK and LITIGATION RISK, neither CAREER RISK $(\mathrm{t}=1.75, \mathrm{p}=.082, \mathrm{LLCI}=-.026, \mathrm{ULCI}=.420)$ nor LITIGATION RISK $(\mathrm{t}=.481, \mathrm{p}=.631, \mathrm{LLCI}=-.169, \mathrm{ULCI}=.278)$ are significant mediators of the relation between RED FLAGS and EXTERNALLY. In other words, these concerns over long-term costs did not ultimately affect the reporting behavior of our participants. ${ }^{27}$

\subsection{Job tenure and reporting earnings quality concerns}

In relation to the sham-account sales scandal at Wells Fargo (that led to the ouster of the CEO, substantial fines, etc.), Wells Fargo executives reported to the press that the "root of Wells Fargo's crisis-control debacle is an insular corporate culture, fostered by executives with decades of tenure" (Glazer 2016). Likewise, in his study of white collar criminals, Soltes (2016) notes

\footnotetext{
${ }^{27}$ We find these non-significant results regardless of the level of PRESSURE.
} 
that "when individuals become more senior in an organization, they tend to be more susceptible to overconfidence and trust their own ability to successfully navigate challenges." Schrand and Zechman (2012) observe that overconfident executives are more inclined to start down the slippery slope of intentionally misstating their financial statements.

Given the prior discussion of short- and long-term career concerns, we examine correlations between our participants' experience/tenure at their position (variable 9 in Table 1) and INTERNALLY and EXTERNALLY. With respect to reporting when RED FLAGS are present, both correlations were negative, with INTERNALLY approaching significance $(\mathrm{p}=$ .126) and EXTERNALLY marginally significant $(\mathrm{p}=.072)$. Thus, we provide initial evidence that corporate managers with longer tenure at their positions are less likely to "rock the boat" and report concerns over earnings quality externally. It is possible that longer-tenured employees are more concerned about short-term costs because they are further in their careers, meaning longterm effects may be less relevant (e.g., they are more likely to retire sooner holding their same position and are less likely to obtain a future management position at another company).

\subsection{The professional accountant's role in reporting concerns}

As described in Table 1 (variable 12), $41.32 \%$ of our sample participants indicated that their background was in public accounting (versus finance, credit, investment banking). IFAC (2016) notes: "A distinguishing mark of the accountancy professional is its acceptance of the responsibility to act in the public interest." In addition, if a misstatement is later identified, the CFO with an accounting background is more likely to be held responsible for the error or fraud (versus a CFO with finance experience who may be able to deflect responsibility to a corporate controller). Provided this added incentive for managers with public accounting backgrounds to report earnings quality concerns, we examine correlations between a public accounting 
background (variable 12 in Table 1) and the likelihood of reporting concerns INTERNALLY and EXTERNALLY. When RED FLAGS are present, both correlations were positive, with INTERNALLY approaching significance $(\mathrm{p}=.119)$ and EXTERNALLY significant $(\mathrm{p}=.012)$. Consistent with the recent ethical framework set forth by IFAC (2016), we observe that, when fraud red flags are present, managers with public accounting backgrounds are more likely to report externally.

\subsection{Examination of only CFO participants}

Seventy-nine (38.73\%) of our participants hold the management role of CFO at their respective companies (versus controller, financial accounting manager). While examining the responses of only CFOs substantially reduces our sample size, we observe that our inferences related to our hypotheses remain the same except for $\mathrm{H} 2 \mathrm{~b}$. When examining the responses of only CFOs, the positive effect of RED FLAGS on INTERNALLY is stronger when PRESSURE is higher (see Table 5 and Figure 5). A comparison of Figures 3 and 5 suggests the difference in results are due to CFO participants, when RED FLAGS are present and PRESSURE is low, being more hesitant to report INTERNALLY (mean $=3.14$, see Figure 5) than our full sample that also contains controllers, finance directors, etc. (mean $=4.20$, see Figure 3$)$. It is possible that CFO participants who observe RED FLAGS under low PRESSURE are less inclined to "jump the gun" and discuss their concerns with their CEO. They may be more inclined to address their concerns over earnings quality with their subordinates responsible for preparing the financial statements. However, we do not observe a strong inclination for our CFO participants to talk to either their corporate controller or divisional controllers when RED FLAGS are present and PRESSURE is low (means $=3.33$ and 3.14 , respectively). This lack of response from our CFOs participants is concerning as it suggests that CFOs are prone to fall down the "slippery 
slope" that could result in them having to actively participate in intentional misreporting in future periods to unwind any past, opportunistic earnings management that was not nipped at the bud (Schrand and Zechman 2012).

\section{Conclusion}

Management is tasked with preventing and detecting extreme earnings management at companies, as it is both costly and undermines public confidence in the markets. Consequently, it is important for us to not only understand whether managers are able to recognize the red flags that indicate earnings management, but also whether they are willing to respond to such risks by reporting concerns to the appropriate party(ies). In this study, we observe that managers' concerns over earnings quality increase when red flags are present in the financial statements they review. In addition, when the pressure to meet a financial target is greater, managers are more concerned about earnings quality when reviewing financial statements exhibiting red flags.

We also document that when red flags are present, managers are more likely to report both internally to their CEO and, if their concerns are not resolved internally, externally to their auditor. Although pressure to meet a financial target directly impacts reporting internally, it does not moderate the positive relation we observe between the presence of red flags and the likelihood of reporting internally and externally. Last, we examine the countervailing costs to reporting earnings quality concerns. We find that managers perceive both short-term and longterm job costs to reporting, but only the short-term costs impact the likelihood that they report externally. 


\section{References}

American Institute of Certified Public Accountants (AICPA), 2015. AU Section 240: Consideration of fraud in a financial statement audit. New York, NY: AICPA.

Ashton, R., 1990. Pressure and performance in accounting decision settings: Paradoxical effects of incentives, feedback, and justification. Journal of Accounting Research 28: 148-180.

Association of certified fraud examiners (ACFE), 2014. Report to the nations on occupational fraud and abuse: 2014 global fraud study. Austin, TX: ACFE.

ACFE, 2016. Report to the nations on occupational fraud and abuse: 2016 global fraud study. Austin, TX: ACFE.

Baumeister, R, 1984. Choking under pressure: Self-consciousness and paradoxical effects of incentives on skillful performance. Journal of Personality and Social Psychology 46: 61020.

Beasley, M, 1996. An empirical analysis of the relation between the board of director composition and financial statement fraud. The Accounting Review 71 : 443-465.

Beasley, M., J. Carcello, D. Hermanson, and T. Neal, 2010. Fraudulent Financial Reporting: 1998-2007 An analysis of U.S. public companies. Committee of Sponsoring Organizations of the Treadway Commission.

Bianchi, P. 2017. Auditors' joint engagement and audit quality: evidence from Italian private companies. Contemporary Accounting Research (forthcoming).

Bonacchi, M., F. Cipollini, and P. Zarowin. 2017. Parents use of subsidiaries to "push down" earnings management: evidence from Italy. Contemporary Accounting Research (forthcoming). 
Brazel, J., K. Jones, and M. Zimbelman, 2009. Using nonfinancial measures to assess fraud risk. Journal of Accounting Research 47: 1135-1166

Brazel, J., K. Jones, and D. Prawitt, 2014. Auditors' reactions to inconsistencies between financial and nonfinancial measures: The interactive effects of fraud risk assessment and a decision prompt. Behavioral Research in Accounting 26: 131-156.

Brazel, J., S. Jackson, T. Schaefer, and B. Stewart, 2016a. The outcome effect and professional skepticism. The Accounting Review 91: 1577-1599.

Brazel, J., T. Carpenter, K. Jones, and J. Thayer, 2016b. Transparent disclosure and fraud risk: Evaluating investors' responses to red flags. Working Paper, North Carolina State University.

Brink, A., D. Lowe, and L. Victoravich, 2013. The effect of evidence strength and internal rewards on intentions to report fraud in the Dodd-Frank regulatory environment. Auditing: A Journal of Practice \& Theory 32: 87-104.

Brislin, R. W., 1986. The wording and translation of research instrument. Field Methods in Crosscultural Research. Series 8: 137-164.

Burgstahler, D. and M. Eames, 2006. Management of earnings and analysts' forecasts to achieve zero and small positive earnings surprise. Journal of Business Finance and Accounting 33: 633-652.

Burgstahler, D., L. Hail, and C. Leuz, 2006. The importance of reporting incentives: Earnings management in European private and public firms. The Accounting Review 81: 9831016.

Callao, S. and J. Jarne, 2010. Have IFRS affected earnings management in the European Union? Accounting in Europe 7: 159-189.

Carson, T., M. Verdu, and R. Wokutch, 2008. Whistle-blowing for profit: An ethical analysis of the Federal False Claims Act. Journal of Business Ethics 77: 361-376.

Cressey, D, 1953. Other people's money: The social psychology of embezzlement. New York: Free Press.

Dechow, P., R. Sloan, and A. Sweeney. 1996. Causes and consequences of earnings manipulation: An analysis of firms subject to enforcement actions by the SEC. Contemporary Accounting Research 13: 1-36.

Dechow, P., W. Ge, C. Larson, and R. Sloan, 2011. Predicting material accounting misstatements. Contemporary Accounting Research 28: 17-82.

DeFond, M., and J. Jiambalvo. 1994. Debt covenant violation and manipulation of accruals. Journal of Accounting and Economics 17: 145-176.

Dichev, I., J. Graham, C. Harvey, and S. Rajgopal, 2013. Earnings quality: Evidence from the field. Journal of Accounting and Economics 56: 1-33.

Dyck, A., A. Morse, and L. Zingales, 2010. Who blows the whistle on corporate fraud? The Journal of Finance 65: 2213-2253.

Estes, W, 1986. Array models for category learning. Cognitive Psychology 18: 500-549.

Evans, M., R. Houston, M. Peters, and J. Pratt, 2015. Reporting regulatory environments and earnings management: U.S. and Non-U.S. firms using U.S. GAAP or IFRS. The Accounting Review 90: 1969-1994.

Feng, M., W. Ge, S. Lo, and T. Shevlin, 2011. Why do CFOs become involved in material accounting manipulations? Journal of Accounting and Economics 51: 21-36. 
Francis, J., K. Schipper, and L. Vincent, 2003. The relative and incremental explanatory power of earnings and alternative (to earnings) performance measures for returns.

Contemporary Accounting Research 20: 121-164.

Glazer, E., 2016. Wells Fargo's botched crisis management. Wall Street Journal October: A1.

Graham, J., C. Harvey, and S. Rajgopal, 2005. The economic implications of corporate financial reporting. Journal of Accounting and Economics 40: 3-73.

Gullkvist, B., and A. Jokipii, 2013. Perceived importance of red flags across fraud types. Critical Perspectives on Accounting 24: 44 - 61.

Hayes, A., 2013. Introduction to mediation, moderation, and conditional process analysis. New York, NY: The Guilford Press.

Hennes, K., A. Leone, and B. Miller, 2008. The importance of distinguishing between errors from irregularities in restatement research. The Accounting Review 83: 1487-1519.

Hogan, C., Z. Rezaee, R. Riley, and U. Velury, 2008. Financial statement fraud: Insights from the academic literature. Auditing: A Journal of Practice \& Theory 27: 231-252.

International Auditing and Assurance Standards Board (IAASB), 2009. ISA 240: The auditor's responsibilities relating to fraud in an audit of financial statements. New York, NY: IFAC.

International Federation of Accountants (IFAC), 2013. The role and expectations of a CFO: A global debate on preparing accountants for finance leadership. New York, NY: IFAC.

International Federation of Accountants (IFAC), 2016. International Ethics Standards Board for Accountants: Responding to non-compliance with laws and regulations. New York, NY: IFAC.

Italian Law No. 262, 2005. Provisions for the protection of savings and regulation of financial markets. Official Journal No. 301. Supplement No. 208.

Jos, P. H., M. Tompkins, and S. Hays, 1989. In praise of difficult people: A portrait of the committed. Public Administration Review 49: 552.

Karpoff, J., D. S. Lee, and G. Martin. 2008. The cost to firms of cooking the books. Journal of Financial and Quantitative Analysis 43: 581-612.

Kinney, W., and R. Martin, 1994. Does auditing reduce bias in financial reporting? A review of audit related adjustment studies. Auditing: A Journal of Practice and Theory 13: 149-156.

Lee, T., R. Ingram, and T. Howard, 1999. The difference between earnings and operating cash flow as an indicator of financial reporting fraud. Contemporary Accounting Research 16: 749-786.

Leoni, G. and C. Florio. A comparative history of earnings management literature from Italy and the US. Accounting History 20: 490-517.

Medin, D. and M. Schaffer, 1978. Context theory of classification learning. Psychological Review 85: 207-238.

Medin, D., R. Goldstone, and D. Gentner, 1993. Respects for similarity. Psychological Review 100: 254-278.

Melis, A., 2005. Corporate governance failures: To what extent is Parmalat a particularly Italian case? Corporate Governance: An International Review 13: 478-488.

Myers, L., S. Scholz, and N. Sharp, 2013. Restating under the radar? Determinants of restatement disclosure choices and the related market reactions. Unpublished Paper. University of Tennessee. 
Nelson, M., J. Elliott, and R. Tarpley, 2003. How are earnings managed? Examples from auditors. Accounting Horizons 17: 17-35.

North American Securities Administrators Association (NASAA), 2006. NASAA Year in review 2006: Advancing a legacy of investor protection. Washington, DC: NASAA.

Public Oversight Board (POB), 2000. The panel on audit effectiveness: Report and recommendations. Stamford, CT: POB.

Public Company Accounting Oversight Board (PCAOB), 2015. AS 2805: Management representations. Washington, DC, 2015.

Robertson, J., C. Stefaniak, and M. Curtis, 2011. Does wrongdoer reputation matter? Impact of auditor-wrongdoer performance and likeability reputations on fellow auditors' intentions to take action and choice of reporting outlet. Behavioral Research in Accounting 23: 207-234.

Scannel, K., and A. Latour, 2004. Raising a red flag isn't enough. Wall Street Journal April: C1.

Schrand, C., and S. Zechman. Executive overconfidence and the slippery slope to financial misreporting. Journal of Accounting and Economics 53: 311-329.

Schultz, J., J. Johnson, D. Morris, and S. Dyrnes, 1993. An investigation of the reporting of questionable acts in an international setting. Journal of Accounting Research 31: 75.

Schultz, J., J. Bierstaker, and E. O’Donnell, 2010. Integrating business risk into auditor judgment about the risk of material misstatement: The influence of a strategic systems audit approach. Accounting, Organizations and Society 35: 238-251.

Soltani, B., 2014. The anatomy of corporate fraud: A comparative analysis of high profile American and European corporate scandals. Journal of Business Ethics 120: 251-274.

Soltes, E. 2016. Why they do it: Inside the mind of the white collar criminal. PublicAffairs: New York.

Taylor, E. and M. Curtis, 2010. An examination of the layers of workplace influences in ethical judgments: Whistleblowing likelihood and perseverance in public accounting. Journal of Business Ethics 93: 21-37.

Van Tendeloo, B., and A. Vanstraelen, 2008. Earnings management and audit quality in Europe: Evidence from the private client segment market. European Accounting Review 17: 447469.

Verschoor, Curtis C, 2012. Proposed global whistleblower standard presents challenges. Strategic Finance 94: 12-16. 
TABLE 1

Demographic Data

\begin{tabular}{|c|c|c|}
\hline \multicolumn{2}{|c|}{ Variables } & $\begin{array}{l}\text { Response } \\
{[n=204]} \\
\text { Mean (Std. Dev.) }\end{array}$ \\
\hline \multicolumn{3}{|c|}{ Participant Variables } \\
\hline 1. & $\% \mathrm{CFO}$ & 38.73 \\
\hline 2. & $\%$ Controller & 27.45 \\
\hline 3. & $\%$ Involved with the production of financial statements & 100.00 \\
\hline 4. & $\%$ Responsible for the financial statements & 83.82 \\
\hline 5. & Search for red flags & $5.28(1.80)$ \\
\hline 6. & Report internally to a superior & $6.33(1.04)$ \\
\hline 7. & Report anonymously to whistleblower hotline & $3.91(2.36)$ \\
\hline 8. & Report externally & $4.22(2.27)$ \\
\hline 9. & Experience at position & $2.76(.86)$ \\
\hline 10. & Age & $1.57(.713)$ \\
\hline 11. & Education & $2.98(.74)$ \\
\hline 12. & $\%$ Background in public accounting & 41.32 \\
\hline \multicolumn{3}{|c|}{ Company Variables } \\
\hline 13. & Sales & $2.58(1.70)$ \\
\hline 14. & Foreign sales & $2.55(1.16)$ \\
\hline 15. & $\%$ Privately held & 81.86 \\
\hline 16. & Company age & $41.83(34.57)$ \\
\hline 17. & $\%$ Manufacturing industry & 20.59 \\
\hline 18. & $\%$ Service/Consulting industry & 12.25 \\
\hline 19. & \% Retail/Wholesale industry & 9.80 \\
\hline 20. & $\%$ Other industry & 35.31 \\
\hline 21. & $\%$ Did not provide industry & 22.05 \\
\hline 22. & $\%$ Audited by an international accounting firm & 65.33 \\
\hline
\end{tabular}

1. \% CFO = Coded 1 if the participant inputted their job title as chief financial officer, 0 otherwise.

2. \% Controller $=$ Coded 1 if the participant inputted their job title as controller, 0 otherwise.

3. \% Involved with the production of financial statements = As part of your current job, are you in anyway involved with producing your company's financial statements? Coded 1 if the participant responded yes, 0 otherwise.

4. \% Responsible for the financial statements = As part of your current job, are you in anyway responsible for your company's financial statements? Coded 1 if the participant responded yes, 0 otherwise.

5. Search for red flags $=$ When you review the financial statements of your company, to what extent do you search for red flags related to fraud? Measured via a scale where $1=$ "Never" and 7 = "Always." 
6. Report internally to a superior = If you identified a fraud red flag while reviewing your company's financial statements, what would be the likelihood you would discuss the fraud red flag with your boss at your company? Measured via a scale where $1=$ "Low Likelihood" and 7 = "High Likelihood."

7. Report anonymously to whistleblower hotline = If you identified a red flag while reviewing your company's financial statements and your company was not responsive to your concern, what would be the likelihood you would report the red flag to your company's anonymous whistleblower hotline? Measured via a scale where 1 = "Low Likelihood" and 7 = "High Likelihood."

8. Report externally = If you identified a red flag while reviewing your company's financial statements and your company was not responsive to your concern, what would be the likelihood you would discuss the red flag with someone outside your company (e.g., external auditor)? Measured via a scale where $1=$ "Low Likelihood" and 7 = "High Likelihood."

9. Experience at position $=$ Your time in job. Measured via a scale where $1=$ " $<4$ years" and $4=$ " $\geq 20$ years"

10. Age $=$ Your age. Measured via a scale where $1=<40$ and 4 " $\geq 60$ years"

11. Education $=$ Your education. Measured via a scale where $1=$ "High school" and $5=$ "non-MBA masters"

12. \% Background in public accounting $=$ Coded 1 if the participant indicated that their background was in public accounting, 0 otherwise.

13. Sales $=$ Sales revenue. Measured via a scale where $1=$ "Less than $\$ 25$ million" and $7=$ "More than $\$ 10$ billion"

14. Foreign sales $=$ Proportion of foreign sales at your company. Measured via a scale where $1=$ " $0 \% "$ and $4=$ " $\geq 50 "$

15. \% Privately held = Is the company you currently work for privately held or publicly traded? Coded 1 if the participant responded privately held, 0 otherwise.

16. Company age $=$ Company age in years inputted by participant.

17. \% Manufacturing industry $=$ Coded 1 if the participant indicated the company was in the manufacturing industry, 0 otherwise.

18. \% Service/Consulting industry $=$ Coded 1 if the participant indicated the company was in the Service/Consulting industry, 0 otherwise.

19. \% Retail/Wholesale industry $=$ Coded 1 if the participant indicated the company was in the Retail/Wholesale industry, 0 otherwise.

20. \% Other industry $=$ Coded 1 if the participant indicated the company was in an industry other than Manufacturing, Service/Consulting, or Retail/Wholesale, 0 otherwise.

21. \% Did not provide industry $=$ Coded 1 if the participant did not provide a company industry, 0 otherwise.

22. \% Audited by an international accounting firm = Is your company's auditor an international accounting firm (e.g., KPMG) or an Italian accounting firm. Coded 1 if participant responded international firm, 0 otherwise. 
TABLE 2

Descriptive Statistics - CONCERN, INTERNALLY, and EXTERNALLY

\begin{tabular}{|c|c|c|c|}
\hline & RED FLAGS not present & RED FLAGS present & PRESSURE main effect \\
\hline $\begin{array}{c}\text { PRESSURE } \\
\text { low }\end{array}$ & $\begin{array}{c}\text { Condition } 1 \\
\text { CONCERN }=0.75(0.76) \\
\text { INTERNALLY }=2.65(1.66) \\
\text { EXTERNALLY }=2.71(2.05) \\
\mathrm{n}=48\end{array}$ & $\begin{array}{c}\text { Condition } 3 \\
\text { CONCERN }=1.46(1.13) \\
\text { INTERNALLY }=4.20(1.93) \\
\text { EXTERNALLY }=4.40(2.30) \\
\mathrm{n}=50\end{array}$ & $\begin{array}{c}\text { CONCERN }=1.11(1.02) \\
\text { INTERNALLY }=3.44(1.95) \\
\text { EXTERNALLY }=3.57(2.33) \\
\mathrm{n}=98\end{array}$ \\
\hline $\begin{array}{c}\text { PRESSURE } \\
\text { high }\end{array}$ & $\begin{array}{c}\text { Condition } 2 \\
\text { CONCERN }=0.84(0.65) \\
\text { INTERNALLY }=3.34(2.20) \\
\text { EXTERNALLY }=2.92(2.34) \\
\mathrm{n}=50\end{array}$ & $\begin{array}{c}\text { Condition } 4 \\
\text { CONCERN }=2.09(0.94) \\
\text { INTERNALLY }=5.46(1.87) \\
\text { EXTERNALLY }=4.16(1.68) \\
\mathrm{n}=56\end{array}$ & $\begin{array}{c}\text { CONCERN }=1.50(1.03) \\
\text { INTERNALLY }=4.46(2.29) \\
\text { EXTERNALLY }=3.61(2.08) \\
\mathrm{n}=106\end{array}$ \\
\hline $\begin{array}{c}\text { RED } \\
\text { FLAGS } \\
\text { main effect }\end{array}$ & $\begin{array}{c}\text { CONCERN }=0.80(0.70) \\
\text { INTERNALLY }=3.00(1.97) \\
\text { EXTERNALLY }=2.85(2.19) \\
\mathrm{n}=98\end{array}$ & $\begin{array}{c}\text { CONCERN }=1.79(1.08) \\
\text { INTERNALLY }=4.87(1.99) \\
\text { EXTERNALLY = } 4.27(1.99) \\
\mathrm{n}=106\end{array}$ & \\
\hline
\end{tabular}

Table 2 reports the mean levels (standard deviations) for CONCERN, INTERNALLY, and EXTERNALLY in each of the four experimental groups and for the main effects of RED FLAGS and PRESSURE. Our first dependent variable is the level of the manager's concern over earnings quality (CONCERN). After reviewing the experimental materials, participants responded to the following prompt:

"Based on your preliminary review, net income for Tecno in 2013 is:"

Participants responded on a 7-point response scale ranging from 1 to 7 , with the left endpoint labeled "Materially understated" and the right endpoint labeled "Materially overstated." The middle of the scale, which was 4, was labeled "Very accurate." We measure CONCERN as the absolute value of the participant's response from the midpoint of 4 (that earnings are very accurate). Our other dependent variables of interest are the likelihood that the manager will report concerns over earnings quality internally (INTERNALLY) and externally (EXTERNALLY). We measured INTERNALLY with the following question:

"You stated that the 2013 net income for Tecno may be overstated/understated. To what extent would you discuss this concern with your Chief Executive Officer (CEO)?"

Participants responded on a 7-point response scale ranging from 1 to 7, with the left endpoint labeled "Would not discuss" and the right endpoint labeled "Definitely discuss."

We measured EXTERNALLY with the following question:

"You stated that the 2013 net income for Tecno may be overstated/understated. If inside your company nothing was done in response to your concern, to what extent would you discuss this concern with your external auditor?"

Participants responded on a 7-point response scale ranging from 1 to 7 , with the left endpoint labeled "Would not discuss" and the right endpoint labeled "Definitely discuss." Participants responding " 4 " to CONCERN were coded as "1" or "Would not discuss" in the INTERNALLY and EXTERNALLY scales described above. 
TABLE 3

ANOVA: H1a and H1b Testing - CONCERN ${ }^{a}$

\begin{tabular}{lcccc} 
& \multicolumn{3}{c}{ Mean } & $p^{\mathbf{c}}$ \\
Independent Variables & df & square & $F$ & $<0.001$ \\
\hline RED FLAGS & 1 & 48.74 & 61.481 & 0.004 \\
PRESSURE & 1 & 6.575 & 8.286 & 0.032 \\
RED FLAGS X PRESSURE & 1 & 3.696 & 4.658 & \\
Error & 200 & .793 & & \\
\hline
\end{tabular}

${ }^{a}$ CONCERN $=$ After reviewing the experimental materials, participants responded to the following prompt:

"Based on your preliminary review, net income for Tecno in 2013 is:"

Participants responded on a 7-point response scale ranging from 1 to 7 , with the left endpoint labeled "Materially understated" and the right endpoint labeled "Materially overstated." The middle of the scale, which was 4, was labeled "Very accurate." We measure CONCERN as the absolute value of the participant's response from the midpoint of 4 (that earnings are very accurate).

${ }^{\mathrm{b}}$ RED FLAGS = Manipulated as present (both the accrual and NFM red flag were present) or not present (both the accrual and NFM red flag were not present).

PRESSURE $=$ Manipulated as high (ratio for percent return on assets just barely meets the required ratio as stated in the debt covenant) and low (ratio for percent return on assets easily exceeds the required ratio as stated in the debt covenant).

${ }^{\mathrm{c}}$ All tests are two-tailed. 
TABLE 4

MANOVA: INTERNALLY \& EXTERNALLY - Full Sample ${ }^{a}$

\begin{tabular}{|c|c|c|c|c|c|}
\hline Independent Variables ${ }^{\mathbf{b}}$ & & df & $\begin{array}{l}\text { Mean } \\
\text { square }\end{array}$ & $F$ & $p^{\mathbf{c}}$ \\
\hline \multirow[t]{2}{*}{ RED FLAGS (RF) } & INTERNALLY & 1 & 172.32 & 46.360 & $<0.001$ \\
\hline & EXTERNALLY & 1 & 104.337 & 23.799 & $<0.001$ \\
\hline \multirow[t]{2}{*}{ PRESSURE } & INTERNALLY & 1 & 47.826 & 12.867 & $<0.001$ \\
\hline & EXTERNALLY & 1 & 0.013 & 0.003 & 0.957 \\
\hline \multirow[t]{2}{*}{ RF X PRESSURE } & INTERNALLY & 1 & 4.306 & 1.158 & 0.283 \\
\hline & EXTERNALLY & 1 & 3.295 & 0.752 & 0.387 \\
\hline \multirow[t]{2}{*}{ Error } & INTERNALLY & 199 & 3.717 & & \\
\hline & EXTERNALLY & 199 & 4.384 & & \\
\hline
\end{tabular}

${ }^{\mathrm{a}}$ INTERNALLY = After reviewing the experimental materials, participants responded to the following prompt:

"You stated that the 2013 net income for Tecno may be overstated/understated. To what extent would you discuss this concern with your Chief Executive Officer (CEO)?"

Participants responded on a 7-point response scale ranging from 1 to 7 , with the left endpoint labeled "Would not discuss" and the right endpoint labeled "Definitely discuss."

EXTERNALLY = After reviewing the experimental materials, participants responded to the following prompt:

"You stated that the 2013 net income for Tecno may be overstated/understated. If inside your company nothing was done in response to your concern, to what extent would you discuss this concern with your external auditor?"

Participants responded on a 7-point response scale ranging from 1 to 7 , with the left endpoint labeled "Would not discuss" and the right endpoint labeled "Definitely discuss."

${ }^{\mathrm{b}}$ RED FLAGS (RF) = Manipulated as present (both the accrual and NFM red flag were present) or not present (both the accrual and NFM red flag were not present).

PRESSURE = Manipulated as high (ratio for percent return on assets just barely meets the required ratio as stated in the debt covenant) and low (ratio for percent return on assets easily exceeds the required ratio as stated in the debt covenant).

${ }^{c}$ All tests are two-tailed. 
TABLE 5

MANOVA: INTERNALLY \& EXTERNALLY - CFO Participants ${ }^{\mathrm{a}}$

\begin{tabular}{|c|c|c|c|c|c|}
\hline Independent Variables $\mathbf{b}$ & & $\mathrm{df}$ & $\begin{array}{l}\text { Mean } \\
\text { square }\end{array}$ & $F$ & $p^{\mathbf{c}}$ \\
\hline \multirow[t]{2}{*}{ RED FLAGS (RF) } & INTERNALLY & 1 & 31.120 & 7.881 & 0.006 \\
\hline & EXTERNALLY & 1 & 16.717 & 3.487 & 0.066 \\
\hline \multirow[t]{2}{*}{ PRESSURE } & INTERNALLY & 1 & 33.469 & 8.476 & 0.005 \\
\hline & EXTERNALLY & 1 & 0.764 & 0.159 & 0.691 \\
\hline \multirow[t]{2}{*}{ RF X PRESSURE } & INTERNALLY & 1 & 22.665 & 5.740 & 0.019 \\
\hline & EXTERNALLY & 1 & 1.403 & 0.293 & 0.590 \\
\hline \multirow[t]{2}{*}{ Error } & INTERNALLY & 74 & 3.949 & & \\
\hline & EXTERNALLY & 74 & 4.794 & & \\
\hline
\end{tabular}

${ }^{a}$ INTERNALLY = After reviewing the experimental materials, participants responded to the following prompt:

"You stated that the 2013 net income for Tecno may be overstated/understated. To what extent would you discuss this concern with your Chief Executive Officer (CEO)?"

Participants responded on a 7-point response scale ranging from 1 to 7 , with the left endpoint labeled "Would not discuss" and the right endpoint labeled "Definitely discuss."

EXTERNALLY = After reviewing the experimental materials, participants responded to the following prompt:

"You stated that the 2013 net income for Tecno may be overstated/understated. If inside your company nothing was done in response to your concern, to what extent would you discuss this concern with your external auditor?"

Participants responded on a 7-point response scale ranging from 1 to 7 , with the left endpoint labeled "Would not discuss" and the right endpoint labeled "Definitely discuss."

${ }^{\mathrm{b}}$ RED FLAGS (RF) = Manipulated as present (both the accrual and NFM red flag were present) or not present (both the accrual and NFM red flag were not present).

PRESSURE $=$ Manipulated as high (ratio for percent return on assets just barely meets the required ratio as stated in the debt covenant) and low (ratio for percent return on assets easily exceeds the required ratio as stated in the debt covenant).

${ }^{\mathrm{c}}$ All tests are two-tailed. 
Figure 1: Description of the Study's Four Experimental Conditions

\begin{tabular}{|l|l|l|}
\cline { 2 - 3 } \multicolumn{1}{c|}{} & \multicolumn{1}{|c|}{ RED FLAGS not present } & \multicolumn{1}{c|}{ RED FLAGS present } \\
\hline PRESSURE low & $\begin{array}{l}\text { Condition 1 } \\
\text { Accrual red flag not present } \\
\text { NFM red flag not present } \\
\text { Ratio for percent return on } \\
\text { assets easily exceeds the } \\
\text { required ratio as stated in the } \\
\text { debt covenant }\end{array}$ & $\begin{array}{l}\text { Condion } 3 \\
\text { Accrual red flag present } \\
\text { NFM red flag present } \\
\text { Ratio for percent return on } \\
\text { assets easily exceeds the } \\
\text { required ratio as stated in the } \\
\text { debt covenant }\end{array}$ \\
\hline PRESSURE high & $\begin{array}{l}\text { Condition 2 } \\
\text { Accrual red flag not present } \\
\text { NFM red flag not present } \\
\text { Ratio for percent return on } \\
\text { assets just barely meets the } \\
\text { required ratio as stated in the } \\
\text { debt covenant }\end{array}$ & $\begin{array}{l}\text { Accrual red flag present } \\
\text { NFM red flag present } \\
\text { Ratio for percent return on } \\
\text { assets just barely meets the } \\
\text { required ratio as stated in the } \\
\text { debt covenant }\end{array}$ \\
\hline
\end{tabular}


Figure 2: Graph of Mean Responses to CONCERN

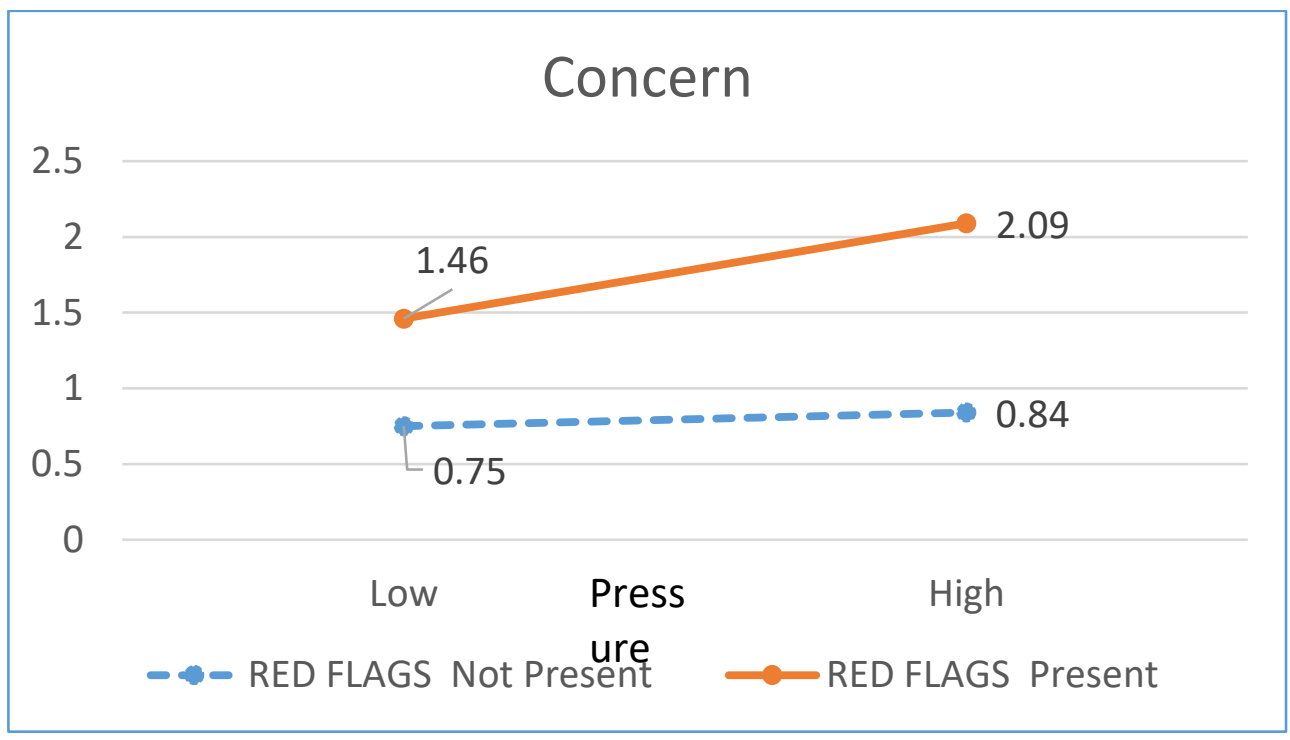

CONCERN $=$ After reviewing the experimental materials, participants responded to the following prompt:

"Based on your preliminary review, net income for Tecno in 2013 is:"

Participants responded on a 7-point response scale ranging from 1 to 7 , with the left endpoint labeled "Materially understated" and the right endpoint labeled "Materially overstated." The middle of the scale, which was 4, was labeled "Very accurate." We measure CONCERN as the absolute value of the participant's response from the midpoint of 4 (earnings are very accurate).

RED FLAGS $=$ Manipulated as present (both the accrual and NFM red flag were present) or not present (both the accrual and NFM red flag were not present).

PRESSURE $=$ Manipulated as high (ratio for percent return on assets just barely meets the required ratio as stated in the debt covenant) and low (ratio for percent return on assets easily exceeds the required ratio as stated in the debt covenant). 
Figure 3: Graph of Mean Responses to INTERNALLY - Full Sample

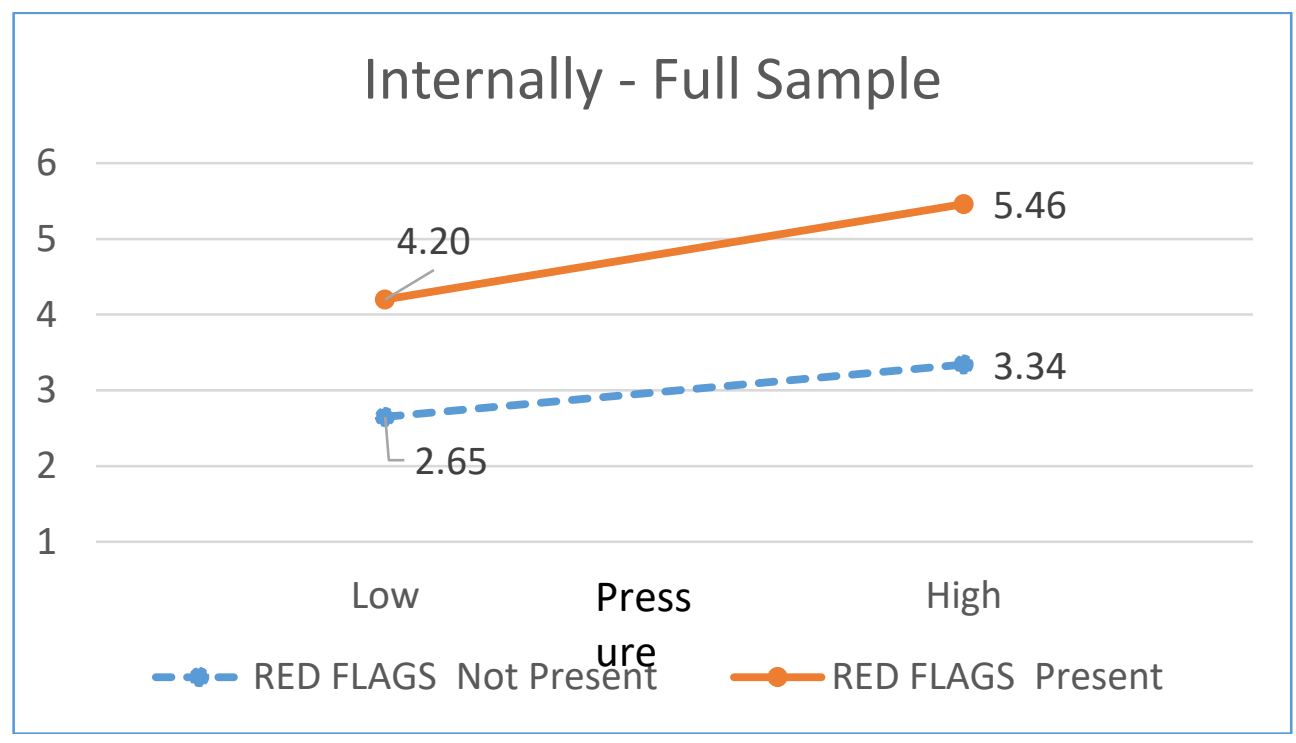

INTERNALLY = After reviewing the experimental materials, participants responded to the following prompt:

"You stated that the 2013 net income for Tecno may be overstated/understated. To what extent would you discuss this concern with your Chief Executive Officer (CEO)?"

Participants responded on a 7-point response scale ranging from 1 to 7 , with the left endpoint labeled "Would not discuss" and the right endpoint labeled "Definitely discuss."

RED FLAGS = Manipulated as present (both the accrual and NFM red flag were present) or not present (both the accrual and NFM red flag were not present).

PRESSURE $=$ Manipulated as high (ratio for percent return on assets just barely meets the required ratio as stated in the debt covenant) and low (ratio for percent return on assets easily exceeds the required ratio as stated in the debt covenant). 
Figure 4: Graph of Mean Response to EXTERNALLY - Full Sample

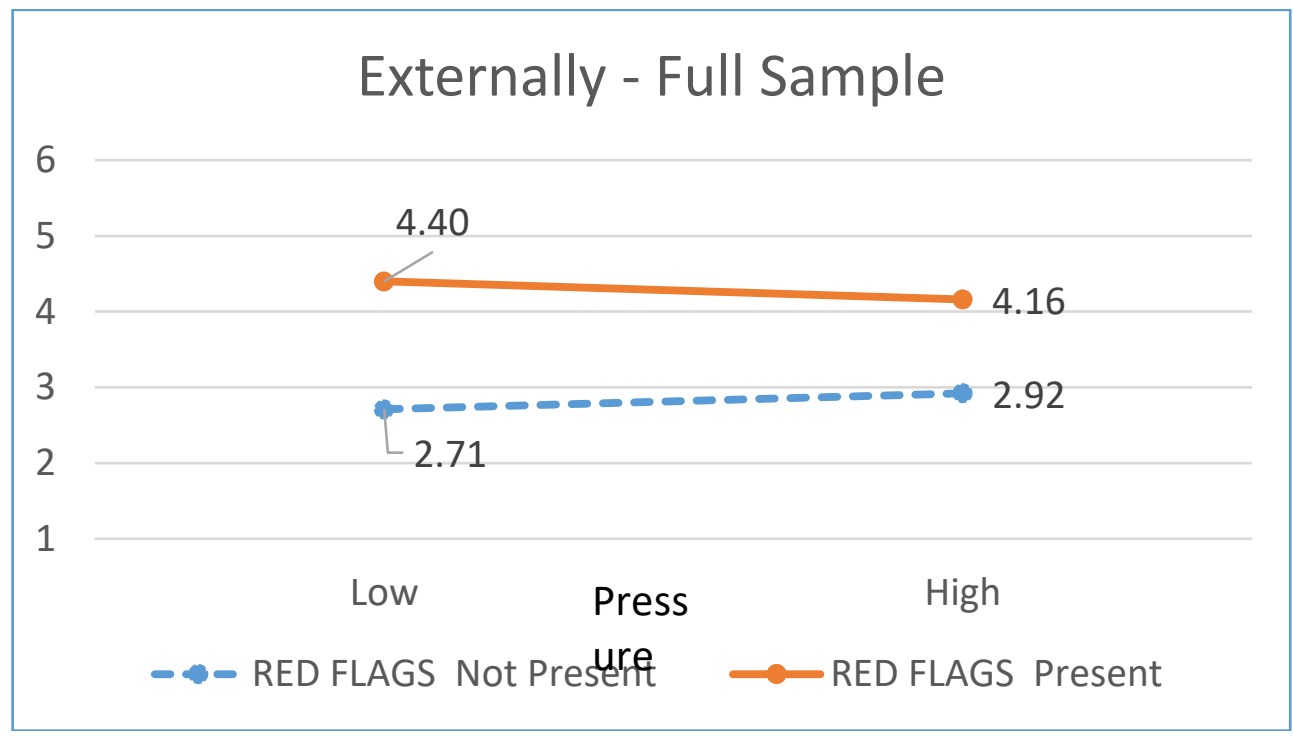

EXTERNALLY $=$ After reviewing the experimental materials, participants responded to the following prompt:

"You stated that the 2013 net income for Tecno may be overstated/understated. If inside your company nothing was done in response to your concern, to what extent would you discuss this concern with your external auditor?"

Participants responded on a 7-point response scale ranging from 1 to 7, with the left endpoint labeled "Would not discuss" and the right endpoint labeled "Definitely discuss."

RED FLAGS = Manipulated as present (both the accrual and NFM red flag were present) or not present (both the accrual and NFM red flag were not present).

PRESSURE = Manipulated as high (ratio for percent return on assets just barely meets the required ratio as stated in the debt covenant) and low (ratio for percent return on assets easily exceeds the required ratio as stated in the debt covenant). 
Figure 5: Graph of Mean Response to INTERNALLY - CFO Participants

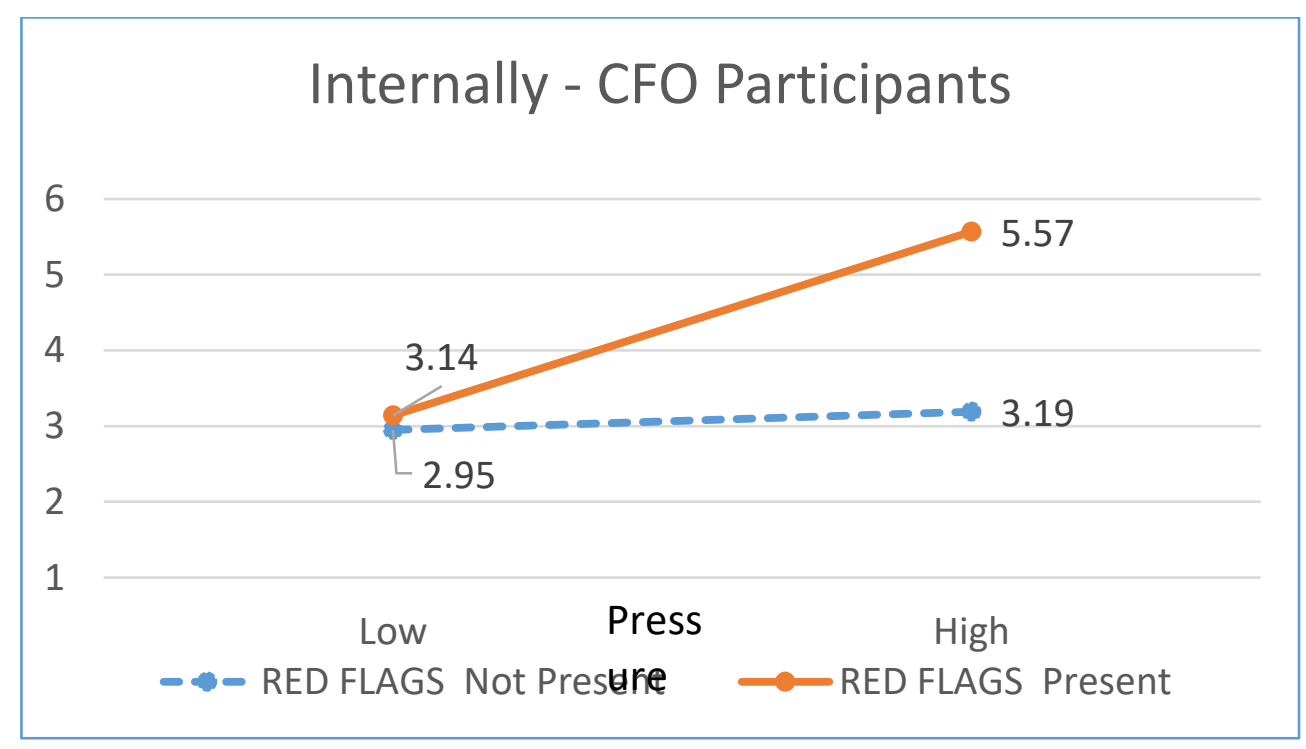

INTERNALLY = After reviewing the experimental materials, participants responded to the following prompt:

"You stated that the 2013 net income for Tecno may be overstated/understated. To what extent would you discuss this concern with your Chief Executive Officer (CEO)?"

Participants responded on a 7-point response scale ranging from 1 to 7 , with the left endpoint labeled "Would not discuss" and the right endpoint labeled "Definitely discuss."

RED FLAGS = Manipulated as present (both the accrual and NFM red flag were present) or not present (both the accrual and NFM red flag were not present).

PRESSURE $=$ Manipulated as high (ratio for percent return on assets just barely meets the required ratio as stated in the debt covenant) and low (ratio for percent return on assets easily exceeds the required ratio as stated in the debt covenant). 